\title{
Оценка перспективных гибридов картофеля для условий Иркутской области
}

\section{Н.И. Большешапова, С.П. Бурлов}

В статье представлены исследования продуктивности и качества гибридов картофеля в Иркутском государственном аграрном университете имени А.А. Ежевского. По результатам трехлетнего изучения питомника конкурсного испытания картофеля в лесостепной зоне Иркутской области, по комплексу хозяйственно полезных признаков отобраны гибриды, представляющие интерес для селекции и возделывания в производстве.

Ключевые слова: картофель, гибрид, качество, крахмал, урожайность.

орт - основа технологии картофелеводства. Селекция новых сортов картофеля для с.х. производства Иркутской области продолжается по требованиям крупных товаропроизводителей.

Картофель для производства должен обладать рядом характеристик. Сорт картофеля должен быть среднеранний с высокой урожайностью, обладать хорошими вкусовыми и кулинарными качествами, иметь устойчивость к патогенам. Это поможет преодолеть потери урожая от вирусных, грибковых заболеваний, вредителей, которые несет картофельное производство нашего региона.

Цель исследований: изучить и дать оценку гибридам картофеля по количественным и качественным показателям для дальнейшего использования их в селекционных программах.

Исследования проводили на опытном поле кафедры земледелия и растениеводства Иркутского ГАУ в 20132015 годах. Почва опытного участка - серая лесная. Пахотный горизонт мощностью 25-30 см, содержание гумуса 3-4\%, окиси фосфора 25-30 мг, окиси калия 5-6 мг на 100 г почвы, pH 5,6-6; степень насыщенности основаниями 80-90\%. Картофель размещался в севообороте: пар - картофель - пшеница. Технология возделывания типичная для зональных условий. Удобрения вносили весной в дозах $\mathrm{N}_{60} \mathrm{P}_{90} \mathrm{~K}_{90}$ кг д.в. на 1 га.

В питомнике конкурсного испытания изучали гибриды, полученные на кафедре земледелия и растениеводства Иркутского ГАУ. Стандарт - районированный в Иркутской области сорт
Сарма. В работе использовали: методика Государственного сортоиспытания с.- х. культур [1]; уборка урожая проводили сплошным методом; крахмалистость клубней определяли по удельному весу; сухое вещество - методом высушивания. Статистическая обработка результатов исследований по Доспехову Б.А. [2].

В опыте изучили 10 гибридов картофеля, полученные на кафедре, и районированный сорт Сарма (табл. 1).

Цвет мякоти гибридов варьирует: белая у ВК-1-1, кремовая - ЛТ11-13, ЛТ-11-02, у остальных гибридов светло-желтая и желтая окраска мякоти.

Bce гибриды имели округлоовальную форму со средними и поверхностями глазками.

Сорта, с коротким вегетационным периодом, всходят и растут гораздо быстрее и дают более высокие урожаи в ранние сроки [3]

У гибридов, посаженных 24 мая, всходы появились на 20-25 день. Первые всходы наблюдали у сорта Красное лето (12.06) и гибридов ЛТ11-13, лт-11-02 (13.06), остальные гибриды всходили на 2-3 дня позже.

Вегетационный период изучаемых гибридов составил от 84 до 92 дней. Наиболее коротким был период «бутонизация-цветение» до 7 дней у гибридов ВК-1-1, ВК-2-13, ДР-11. Естественное усыхание ботвы у гибридов картофеля, в годы исследования не наблюдалось.

Продолжительным был период «цветение-отмирание ботвы» от 54 (у гибрида 22009) до 64 дней (CO-11-17).
Анализ продуктивности гибридов картофеля показал, что их урожайность составляла от 13,0 до 30,2 т/га. В результате оценки гибридов, нами выделены 4 образца, обладающие высокой урожайностью - 22009 (30,2 т/га), лТ-13-11 (29,9 т/га), лТ11-13 (28,9 т/га), ВК-1-1 (28,6 т/га), которые равны или превысили стандарт сорт Сарма на 0,5-2,1 т/га. У остальных образцов урожайность была ниже стандарта.

Максимальное количество клубней в кусте имели 22009 (10,3 шт.) и лТ-11-13 (10,0 шт.). По массе товарного клубня (112-168 г) гибриды соответствовали требованиям, предъявляемым к столовым сортам.

Фракционный состав гибридов картофеля показал, наибольший выход крупной фракции обеспечивали ВК-1-1 (95\%), ВК-2-13 (88\%). По выходу средней фракции выделились следующие СО-11-17 (54\%), ЛТ-11$13(54 \%)$

Высокоурожайные гибриды 22009, ЛТ-13-11, ЛТ-11-13, ВК-11 имели выход крупной фракции в среднем 37-95\% соответственно. Нами выделены 2 гибрида обладающие многоклубневостью в сочетании с урожайностью (табл. 2).

Наличие крахмала в клубнях картофеля варьируется в зависимости

\begin{tabular}{|c|c|}
\hline Сорт & Гибридная комбинация \\
\hline Сарма (St.) & Санте $\times$ Огонёк \\
\hline лТ-13-11 & Лазурит × Томич \\
\hline лТ-11-13 & Лазурит × Томич \\
\hline BK-1-1 & Сеянец ВК-1 \\
\hline лТ-11-02 & Лазурит × Томич \\
\hline BK-2-13 & Сеянец ВК-2 \\
\hline ДР-11 & Дельфин × Ромео \\
\hline РБ-1 & Ромео × Бурен \\
\hline $\mathrm{CO}-11-17$ & Санте $\times$ Очарование \\
\hline Красное лето & Ред Скарлет × 9778-1 \\
\hline 22009 & Сеянец 278 \\
\hline
\end{tabular}


Таблица 2. Урожайность и качество гибридов картофеля, 2013-2015 годы

\begin{tabular}{|c|c|c|c|c|c|c|}
\hline \multirow{2}{*}{ Сорт } & \multirow{2}{*}{$\begin{array}{c}\text { Средняя } \\
\text { урожай- } \\
\text { ность, т/га }\end{array}$} & \multicolumn{2}{|c|}{$+/-\mathrm{K} S t$} & \multirow{2}{*}{$\begin{array}{l}\text { Товар- } \\
\text { ность,\% }\end{array}$} & \multirow{2}{*}{$\begin{array}{l}\text { Сухое ве- } \\
\text { щество,\% }\end{array}$} & \multirow{2}{*}{$\begin{array}{l}\text { Крах- } \\
\text { мал,\% }\end{array}$} \\
\hline & & т/га & $\%$ & & & \\
\hline 22009 & 30,2 & 2,1 & 7,5 & 93 & 24,1 & 16,6 \\
\hline лТ-13-11 & 29,9 & 1,8 & 6,4 & 91 & 21,7 & 15,6 \\
\hline лТ-11-13 & 28,9 & 0,8 & 2,8 & 91 & 16,9 & 10,9 \\
\hline BK-1-1 & 28,6 & 0,5 & 1,8 & 98 & 21,3 & 15,4 \\
\hline Сарма (St.) & 28,1 & - & 100 & 98 & 23,1 & 15,9 \\
\hline лТ-11-02 & 27,8 & $-0,3$ & $-1,1$ & 91 & 18,0 & 12,2 \\
\hline BK-2-13 & 26,2 & $-1,9$ & $-6,8$ & 100 & 22,5 & 16,9 \\
\hline ДР-11 & 25,0 & $-3,6$ & $-11,0$ & 88 & 17,4 & 11,6 \\
\hline Красное лето & 22,2 & $-5,9$ & $-21,0$ & 91 & 18,4 & 12,5 \\
\hline РБ-1 & 14,8 & $-13,3$ & $-47,3$ & 94 & 16,9 & 10,9 \\
\hline CO-11-17 & 13,0 & $-15,1$ & $-53,7$ & 97 & 14,2 & 8,3 \\
\hline $\mathrm{HCP}_{05}$ & 1,7 & & & & & \\
\hline
\end{tabular}

от сорта, гибрида и является сортовым признаком картофеля [3].

Величина накопления крахмала в клубнях зависит также от их размера. Крахмалистость клубней с одного куста может колебаться от 16 до 25\% [4, 5].

Бурлов С.П., Вильчинская М.В. [6] считают, что биохимический состав клубней картофеля наряду с генотипической обусловленностью в значительной степени зависит от условий выращивания. Наиболее устойчивыми показателями является содержание в клубнях сухого вещества и крахмала.

У изучаемых гибридов содержание сухого вещества составило от 14,2 до 24,1\%. Высокое содержание сухого вещества наблюдали у гибрида $22009(24,1 \%)$ и ВК-2-13 (22,5\%). Высокоурожайные гибриды имеют повышенное содержание крахмала более 15\% (22009, ВК-1-1, ЛТ-1311), среднее содержание крахмала у ЛТ-11-13, ЛТ-11-02, Красное лето $(10,9-12,5 \%)$ и низкое содержание крахмала у СО-11-17-8,3\%. По содержанию крахмала в годы исследований выделили гибриды ВК-2-13 $(16,9 \%), 22009(16,6 \%)$.

Болиева 3.А. [7] отмечает, что при выведении сортов картофеля большое внимание следует уделять столовым качествам клубня, формирование которых зависит не только от генетических факторов, но и от агроклиматических условий возделывания картофеля.

Устойчивость к потемнению мякоти у изучаемых гибридов относительно высокая. Слабое потемнение наблюдалось у сорта Красное лето (7 баллов)

Все гибриды по разваримости получили 8-9 баллов. Отличный вкус был у 22009 (9 баллов), очень хороший вкус (7 баллов) - ВК-2-13, ЛТ-13-11, ЛТ11-02, ДР-11, ЛТ-11-13, РБ-1, ВК-1-1, хороший вкус - Красное лето и СО-1117 (5-6 баллов).

\section{Выводы.}

1. Выделены 4 гибрида, обладающие высокой урожайностью - 22009 (30,2 т/га), ЛТ-13-11 (29,9 т/га), ЛТ11-13 (28,9 т/га), ВК-1-1 (28,6 т/га), которые равны или превысили стандарт сорт Сарма на 0,5-2,1 т/га.

2. Большое количество клубней в кусте имели гибриды 22009 (10,3 шт.) и лТ-11-13 (10,0 шт.). Нами выделены 2 гибрида обладающие многоклубневостью в сочетании с урожайностью. Наибольший выход крупной фракции обеспечивали гибриды ВК-1-1 (95\%), ВК-2-13 (88\%). По выходу средней фракции выделились следующие гибриды СО-1117 (54\%), ЛТ-11-13 (54\%). По массе товарного клубня (112-168 г) гибриды соответствовали требованиям, предъявляемым к столовым сортам.

3. Выделены высокоурожайные гибриды, которые имеют повышенное содержание крахмала более 15\% (гибриды 22009, ВК1-1, ЛТ-13-11), среднее содержание крахмала ЛТ-11-13, ЛТ11-02, Красное лето (10,9-12,5\%) и низкое содержание крахмала СО-11-17-8,3\%.

4. Оценка вкусовых качеств гибридов выявила отличный вкус у гибрида 22009 (9 баллов), очень хороший вкус (7 баллов) - ВК-2-13, лТ13-11, ЛТ-11-02, ДР-11, ЛТ-11-13, РБ-1, BK-1-1.

5. Гибриды, обладающие высокой урожайностью - 22009, ЛТ-1311, ЛТ-11-13, ВК-1-1 рекомендуют- ся для передачи на государственное испытание.

\section{Библиографический список}

1.Методика государственного сортоиспытания сельскохозяйственных культур. Выпуск 1. Общая часть. М.: Колос, 1985. 268 с.

2.Доспехов Б.А. Методика полевого опыта. М.: Агропромиздат, 1985. $351 \mathrm{c}$.

3.Рычков В.А. Селекция среднераннего сорта картофеля устойчивого к болезням и весеннее-летней засухе в условиях Иркутской области. Рекомендации. Иркутск: Изд-во ИрГСХА, 2012. 52 с.

4.Бурлака В.В. Картофелеводство Сибири и Дальнего Востока. М.: Колос, 1986. 195 с.

5.Вильчинская М.В., С.П. Бурлов. Перспективы селекции картофеля в Сибири // Научные исследования и разработки к внедрению в АПК: сб. ст. междунар. науч.- практ. конф. молодых ученых (19-20 апр. 2012 г.). Иркутск, 2012. С. 100-105.

6.Вильчинская М.В., Большешапова Н.И., Бурлов С.П. Агробиологическая оценка гибридов картофеля в условиях лесостепной зоны Восточной Сибири // Вестник ИрГСХА. 2015. № 69. С. 7-14.

7.Болиева З.А., Басиев С.С., Козаева Д.П. Оценка потемнения мякоти сырого и вареного клубня картофеля гибридов селекции ФГБОУ ВО Горский государственный аграрный университет // Известия Горского государственного аграрного университета. 2016. Т. 53. № 2. C. 27-31.

\section{Об авторах \\ Большешапова Надежда}

Ивановна, аспирант кафедры земледелия и растениеводства агрономического факультета, Иркутский государственный аграрный университет имени А.А. Ежевского. Тел. 89086623363.

E-mail: nade1982@mail.ru

Бурлов Сергей Петрович, канд. С. х. наук, доцент кафедры земледелия и растениеводства агрономического факультета, Иркутский государственный аграрный университет имени А.А. Ежевского. Тел. 89501298375

Evaluation of promising potato hybrids for the conditions of the Irkutsk region N.I. Bolsheshapova, postgraduate, Department of Agriculture and Plant Science, Faculty of Agronomy, Irkutsk State Agrarian University named after

A.A. Ezhevskiy. Phone: 89086623363. E-mail: nade1982@mail.ru

S.P. Burlov, PhD, assistant professor, Department of Agriculture and Plant Science, Faculty of Agronomy, Irkutsk State Agrarian University named after

A.A. Ezhevskiy. Phone: 89501298375

Summary. The article presents the research of productivity and quality of potato hybrids in Irkutsk state agrarian University after A.A. Ezhevsky. According to the results of a threeyear study of the nursery competitive testing of potatoes in the forest-steppe zone of the Irkutsk region, the complex of economically useful features selected hybrids of interest for breeding and cultivation in production.

Keywords: potato, hybrid, quality, starch, yield. 